\title{
Dietary supplementation with plant extracts, xantophylls and synthetic antixidants: Effect on fatty acid profile and oxidative stability of frozen stored chicken breast meat
}

\section{J. Koreleski ${ }^{1}$ and S. Świątkiewicz}

\author{
National Research Institute of Animal Production, \\ Department of Animal Nutrition and Feed Science \\ 32-083 Balice, Poland
}

(Received 13 March 2007; revised version 29 May 2007; accepted 6 September 2007)

\begin{abstract}
Chickens from 22 to 42 days of age were fed a basal diet supplemented with $\alpha$-tocopheryl acetate $\left(150 \mathrm{mg} \cdot \mathrm{kg}^{-1}\right)$, extracts of coneflower, thyme or sage $\left(560 \mathrm{mg} \cdot \mathrm{kg}^{-1}\right)$, marigold xantophylls (20 $\mathrm{mg}$ lutein $\left.\mathrm{kg}^{-1}\right)$, mix of synthetic antioxidants $\left(48.6 \mathrm{mg} \cdot \mathrm{kg}^{-1}\right)$ or $\beta$-apo-8-carotenoic acid ethylester $\left(40 \mathrm{mg} \cdot \mathrm{kg}^{-1}\right)$. On day 42 the chickens were slaughtered, breast muscles were excised, frozen $\left(-20^{\circ} \mathrm{C}\right)$ and stored for 6 months.

Dietary supplementation with plant extracts, synthetic antioxidants or pigments did not affect performance. Sage extract increased the level of stearic acid $\left(\mathrm{C}_{18: 0}\right)$, arachidonic acid $\left(\mathrm{C}_{20: 4}\right)$, DHA and n-3 PUFA and decreased oleic acid and $\alpha$-linolenic acid $\left(\mathrm{C}_{18: 3}\right)$ contents and PUFA n-6/n-3 ratio in lipids of stored breast meat. Additives did not favourably affect TBA-RS values in meat. In chickens fed the control diet or supplemented with $150 \mathrm{mg} \cdot \mathrm{kg}^{-1} \alpha$-tocopheryl acetate, stored meat contained 1.72 or $6.45 \mathrm{mcg}^{-1} \mathrm{~g}^{-1} \alpha$-tocopherol, respectively. Dietary synthetic xantophyll negatively influenced sensory indices in boiled meat.
\end{abstract}

KEY WORDS: broiler chickens, meat, plant extracts, synthetic antioxidants, pigments, fatty acids, $\alpha$-tocopherol, TBA-RS

\footnotetext{
* Supported by the Statutory Activity, Project No. 5211.1

${ }^{1}$ Corresponding author: e-mail: jkoreles@izoo.krakow.pl
} 


\section{INTRODUCTION}

Culinary herbs and spices such as marjoram and caraway (Abd El-Alim et al., 1999), ginger (Fuhrman et al., 2000), oregano (Giannenas et al., 2005), sage, savory and borage (Bandonien et al., 2002), catnip, lavender, thyme, hyssop, anise hyssop (Dapkevicius et al., 1998), rosemary (Galobart et al., 2001) constitute a wide group of natural antioxidant sources. Plant antioxidants may act against free radicals formed during lipid metabolism (Halvorsen et al., 2002) and the results of their activity could be in part compared to synthetic antioxidants.

In meat containing more unsaturated fatty acids there is a risk that their profile will change during storage (Jeremiah, 1980). It seems not unlikely that flavonoids, carotenoids, essential oils and other plant substances may affect lipid accumulation in tissues and control the changes during storage of meat. The present study was designed to evaluate the effects of dry extracts of sage, thyme and coneflower, vitamin E, marigold xantophylls, $\beta$-apo-8-carotenoic acid ethylester, and a mixture of synthetic antioxidants supplemented to a diet on performance, fatty acid composition, TBA-RS, vitamin E content, and sensory properties in breast meat of chickens fed diets containing a mixture of rape seed and fish oils.

\section{MATERIAL AND METHODS}

The study was carried out on 320, 22-day-old sexed Cobb chickens (725 g average initial body weight) allocated to 8 groups in 5 replicates, each containing 4 males and 4 females, and kept in cages with wire mesh floors. The control, basal maize-soyabean diet contained, \%: rape seed oil 4 and fish liquid fat 1 (Lysi h.f. Reykjavik, stabilized with ethoxyquin in amount $250 \cdot \mathrm{kg}^{-1}$ ). Fish fat (Tables 1 and 2) contained (in \% of total fatty acids): 4.75 eicosapentaenoic acid (EPA) and 3.55 docosahexaenoic acid (DHA). Vitamin-mineral premix contained no vitamin E or antioxidants. Experimental diets were supplemented (to $1 \mathrm{~kg}$ ) with $150 \mathrm{mg}$ dl- $\alpha$-tocopheryl acetate (Lutavit ${ }^{\circledR}$ E 50, BASF) or 560 $\mathrm{mg}$ dry extracts from purple coneflower (Echinacea purpurea) (more than $2.5 \%$ of polyphenolic substances), thyme (Thymus vulgaris) (phenols, thymol, essential oils) or sage (Salvia officinalis) (flavonoids, essential oils), or with 20 $\mathrm{mg}$ of marigold (Tagetes sp.) xanthophylls (lutein). For comparative purposes synthetic additives were used: $48.6 \mathrm{mg}$ antioxidant preparation (in it: butylated hydroxytoluene $28.6 \mathrm{mg}$, ethoxyquin $14.3 \mathrm{mg}$, butylated hydroxyanisol 5.72 $\mathrm{mg}$ ) or $40 \mathrm{mg} \beta$-apo-8-carotenoic acid ethylester. Diets as mash were fed ad libitum from day 22 to 42 . 
Table 1. Composition of basal diet, $\mathrm{g} \cdot \mathrm{kg}^{-1}$

\begin{tabular}{lclc}
\hline Item & Content & Item & Content \\
\hline Maize & 573.5 & $\mathrm{Crude}$ protein (analysed) & 201 \\
Soyabean meal & 335 & $\mathrm{ME}, \mathrm{MJ} \cdot \mathrm{kg}^{-1}$ & $12.8^{2}$ \\
Rape seed oil & 40 & $\mathrm{Lys}^{3}$ & 12.0 \\
Fish fat, liquid & 10 & $\mathrm{Met}^{3}$ & 5.10 \\
Limestone & 11.5 & $\mathrm{Ca}^{3}$ & 9.30 \\
Dicalcium phosphate & 18 & $\mathrm{P}^{3}$ & 7.15 \\
NaCl & 3 & $\mathrm{P}$ available & \\
DL-methionine, $99 \%$ & 2 & $\alpha$-tocopherol, $\mathrm{mg}^{3} \cdot \mathrm{kg}^{-1,4}$ (analysed) & 15.10 \\
L-lysine HCl, 78 \% & 2 & & \\
Vitamin-mineral premix & 5 & & \\
\hline
\end{tabular}

${ }^{1}$ contained no antioxidants and vit. E, supplied to $1 \mathrm{~kg}$ of diet, IU: vit. A $12000 . \mathrm{D}_{3} 3250 ; \mathrm{mg}: \mathrm{K}_{3}$ 2.25, $\mathrm{B}_{1} 2, \mathrm{~B}_{2} 7.25, \mathrm{~B}_{6} 4.25, \mathrm{~B}_{12} 0.03$, biotin 0.1, Ca-pantotenate 12, niacine 40, folic acid 1.0, choline-Cl 450, Mn 100, Zn 65; Fe 65, Cu 15, J 0.8, Se 0.25 and Co 0.4

2 according to European Table of Energy Values for Poultry Feedstuffs (1989) as a sum of ME content of feed components calculated on base of nutrients content

${ }^{3}$ calculated from Tables of Feed Composition

${ }^{4}$ after supplementing with $150 \mathrm{mg} \alpha$-tocoferyl acetate the diet was analysed to contain 160.69 $\mathrm{mg} \cdot \mathrm{kg}^{-1}$ vit. E in total

Table 2. Fatty acid composition of lipids (\% of total fatty acids) and vitamin E content in oils and in basal experimental diet of grower type

\begin{tabular}{lccc}
\hline Item & Rape seed oil & Fish fat & Basal diet \\
\hline $\mathrm{C}_{14: 0}$ & nd & 7.91 & 0.83 \\
$\mathrm{C}_{16: 0}$ & 3.71 & 10.96 & 6.99 \\
$\mathrm{C}_{16: 1}$ & 0.17 & 10.32 & 1.04 \\
$\mathrm{C}_{18: 0}$ & 1.31 & 1.12 & 1.31 \\
$\mathrm{C}_{18: 1}$ & 45.27 & 13.32 & 28.11 \\
$\mathrm{C}_{18: 2 \mathrm{n}-6}$ & 37.76 & 2.89 & 52.51 \\
$\mathrm{C}_{18: 3 \mathrm{n}-3}$ & 8.39 & 0.65 & 5.45 \\
$\mathrm{C}_{22: 0}$ & 0.22 & nd & 0.09 \\
$\mathrm{C}_{22: 1}$ (EPA) & 0.84 & 17.47 & 0.26 \\
$\mathrm{C}_{20: 5 \mathrm{n}-3}$ (DHA) & nd & 4.75 & 0.30 \\
$\mathrm{C}_{22: 6 \mathrm{n}-3}$ (DHing fatty acids & 0.20 & 3.55 & 0.31 \\
Remaining faty & 27.06 & 2.80 \\
SFA & 2.13 & 20.20 & 9.48 \\
MUFA & 5.64 & 41.11 & 29.42 \\
PUFA & 46.28 & 38.69 & 61.10 \\
Vitamin E, $\mathrm{mg} \cdot \mathrm{kg}^{-1}$ & 48.08 & 56.99 & 15.95 \\
\hline
\end{tabular}

nd - not detected; ${ }^{1}$ gadoleic acid $\mathrm{C}_{20: 1}-18.6 \%, \mathrm{C}_{18: 4}-1.5 \%$ and others

On day 42 of life 4 males and 4 females were slaughtered, right breast muscles (M. pectoralis maior and minor) without skin and outer fat were excised, packed in plastic bags and frozen at $-20^{\circ} \mathrm{C}$. After 6 months the caudal part of the muscle was taken for chemical analyses and sensory testing.

Samples were extracted as described by Folch et al. (1957), saponified, converted to methyl esters (Morrison and Smith, 1964), extracted with hexane and separated. Fatty acid composition was determined with a GC Varian 3400 
gas chromatograph equipped with a CP-Wax $58,25 \mathrm{~m} \times 0.53 \mathrm{~mm}, 1.0 \mu \mathrm{m}$ colum and $\mathrm{He}$ as the carrier gas, $6 \mathrm{ml}$ per min. Peak areas were measured with Star Chromatography Workstation software (Varian Star 4.5).

Thiobarbituric acid reactive substances (TBA-RS) content as a measure of oxidative changes in meat lipids was determined according to Salih et al. (1987) with the modifications of Pikul et al. (1989). Breast meat $\alpha$-tocopherol content was determined with a Merck-Hitachi HPLC equipped with a LiChroCART 250-4 Superspher $100 \mathrm{RP}-18,4 \mu \mathrm{m}$ column and FL, EX. $295 \mathrm{~nm}, \mathrm{Em} .350 \mathrm{~nm}$ detector according to Manz and Phillip (1981). Basal chemical analysis was conducted according to AOAC (1990).

Breast meat was also boiled in slightly salted water and sensory analysis was conducted by a 6-member panel. Smell and taste, juiciness and tenderness were ranked on a 4-point scale for degree of acceptability (2-unacceptable, 3-acceptable, 4-good, 5-very good).

Data were subjected to one-way analysis of variance and differences were examined by Duncan's multiple range test (Statistica, ver. 5.0 PL software).

\section{RESULTS}

The average final body weight of chickens was 2400 g. Plant extracts, $\alpha$-tocopheryl acetate and synthetic antioxidants or pigment added to the basal diet had no effect on body weight gain, feed intake, feed conversion, or on carcass quality indices (Tables 3 and 4).

Table 3. Performance of chickens, $22-42$ days of age

\begin{tabular}{llccc}
\hline Group & \multicolumn{1}{c}{$\begin{array}{c}\text { Supplement } \\
\cdot \mathrm{kg}^{-1}\end{array}$} & $\begin{array}{c}\text { Body weight } \\
\text { gain } \mathrm{g}\end{array}$ & $\begin{array}{c}\text { Feed intake } \\
\mathrm{g}\end{array}$ & $\begin{array}{c}\text { Feed conversion, } \\
\mathrm{kg} \cdot \mathrm{kg}^{-1} \text { of body } \\
\text { weight gain }\end{array}$ \\
\hline I, control & \multicolumn{1}{c}{-} & 1688 & 3110 & 1.84 \\
II & Vitamin E, 150 mg & 1643 & 3045 & 1.85 \\
III & Coneflower extract, 560 mg & 1700 & 3160 & 1.86 \\
IV & Thyme extract, 560 mg & 1711 & 3138 & 1.84 \\
V & Sage extract, 560 mg & 1682 & 3185 & 1.89 \\
VI & Marigold xantophylls, 20 mg & 1642 & 3143 & 1.92 \\
VII & BHT+EQ+BHA, 48.6 mg & 1645 & 3092 & 1.88 \\
VIII & Synth. yellow xantophyll, 40 mg & 1716 & 3110 & 1.82 \\
SEM & & 10.9 & 14.7 & 0.011 \\
\hline
\end{tabular}

Supplementation of diets with sage extract increased stearic acid $\left(\mathrm{C}_{18: 0}\right)$, arachidonic acid $\left(\mathrm{C}_{20: 4}\right)$ and DHA levels and decreased oleic acid $\left(\mathrm{C}_{18: 1}\right)$ and $\alpha$-linolenic acid $\left(\mathrm{C}_{18: 3}\right)$ levels in lipids of stored chicken breast meat in comparison with the control group (Table 5). In breast meat of chickens fed the sagesupplemented diet, the level of polyunsaturated fatty acids n-3 (PUFA n-3) was higher and the PUFA n-6/n-3 ratio in lipids was lower than in groups fed diets with synthetic antioxidants (Table 6). As compared with other groups, a 
Table 4. Results of slaughter analysis

\begin{tabular}{|c|c|c|c|c|c|}
\hline \multirow{2}{*}{ Group } & \multirow{2}{*}{$\begin{array}{c}\text { Supplement } \\
\cdot \mathrm{kg}^{-1}\end{array}$} & \multirow{2}{*}{$\begin{array}{l}\text { Carcass } \\
\text { yield } \\
\%\end{array}$} & \multicolumn{2}{|c|}{$\mathrm{g} \cdot 100 \mathrm{~g}^{-1}$ of carcass } & \multirow{2}{*}{$\begin{array}{c}\text { Weight of } \\
\text { liver, } \\
\mathrm{g} \cdot 100 \mathrm{~g}^{-1} \\
\text { of liveweight }\end{array}$} \\
\hline & & & $\begin{array}{c}\text { breast meat } \\
\text { yield }\end{array}$ & $\begin{array}{c}\text { content of } \\
\text { abdominal fat }\end{array}$ & \\
\hline I, control & - & 75.3 & 24.8 & 1.39 & 1.69 \\
\hline II & Vitamin E, $150 \mathrm{mg}$ & 76.0 & 25.7 & 1.28 & 1.94 \\
\hline III & Coneflower extract, $560 \mathrm{mg}$ & 76.6 & 26.0 & 1. & 1.86 \\
\hline IV & Thyme extract, $560 \mathrm{mg}$ & 76.9 & 24.1 & 1.4 & 1.80 \\
\hline V & Sage extract, $560 \mathrm{mg}$ & 76.1 & 24.7 & 1.24 & 1.90 \\
\hline VI & Marigold xantophylls, $20 \mathrm{mg}$ & 76.5 & 25.7 & 1.55 & 1.88 \\
\hline VII & $\mathrm{BHT}+\mathrm{EQ}+\mathrm{BHA}, 48.6 \mathrm{mg}$ & 76.4 & 25.6 & 1.28 & 2.00 \\
\hline VIII & Synth. yellow xantophyll, $40 \mathrm{mg}$ & 76.4 & 25.3 & 1.63 & 2.03 \\
\hline SEM & & 0.20 & 0.29 & 0.08 & 0.03 \\
\hline
\end{tabular}

Table 5. Selected fatty acids in stored breast meat, $\%$ of total fatty acids

\begin{tabular}{|c|c|c|c|c|c|c|c|c|c|}
\hline Group & $\begin{array}{l}\text { Supplement } \\
\cdot \mathrm{kg}^{-1}\end{array}$ & $\mathrm{C}_{16: 0}$ & $\mathrm{C}_{18: 0}$ & $\mathrm{C}_{18: 1}$ & $\mathrm{C}_{18: 2}$ & $\mathrm{C}_{18: 3}$ & $\mathrm{C}_{20: 4}$ & $\begin{array}{l}\mathrm{C}_{20: 5 \mathrm{n}-3} \\
(\mathrm{EPA})\end{array}$ & $\begin{array}{l}\mathrm{C}_{22: 6 \mathrm{n}-3} \\
\text { (DHA) }\end{array}$ \\
\hline $\mathrm{I}, \mathrm{cc}$ & $N_{0}$ & 11.8 & $7.86^{\mathrm{a}}$ & $29.8^{\mathrm{b}}$ & 31.9 & $.26^{\mathrm{b}}$ & $7.76^{\mathrm{a}}$ & 0.723 & $4.28^{\mathrm{a}}$ \\
\hline II & Vitamin E, $150 \mathrm{mg}$ & 11.7 & $.20^{\mathrm{bc}}$ & $26.2^{\mathrm{a}}$ & 31.1 & $2.06^{\mathrm{ab}}$ & $9.56^{\mathrm{ab}}$ & 0.792 & $5.98^{\mathrm{ab}}$ \\
\hline III & $\begin{array}{l}\text { Coneflower extract, } \\
560 \mathrm{mg}\end{array}$ & 13.2 & $8.46^{\mathrm{abc}}$ & $28.5^{\mathrm{ab}}$ & 29.5 & ab & $8.12^{\mathrm{a}}$ & 0.882 & $5.69^{\mathrm{ab}}$ \\
\hline V & extract, 560 & 12 & 7.9 & 28.6 & 31.9 & 2.2 & 7. & 0.721 & $5.33^{\mathrm{ab}}$ \\
\hline V & ract, & 11. & 9. & 26 & 30.1 & $1.69^{a}$ & $11.23^{\mathrm{b}}$ & 0.628 & $6.83^{\mathrm{b}}$ \\
\hline VI & old xantophylls, & 2.5 & $8.10^{\mathrm{ab}}$ & $27.8^{\mathrm{ab}}$ & 30.7 & $2.08^{\mathrm{ab}}$ & $8.50^{\mathrm{a}}$ & 0.846 & $5.81^{\mathrm{ab}}$ \\
\hline vIl & $\mathrm{Q}+\mathrm{BHA}, 48.6 \mathrm{mg}$ & & & & & & & 0.689 & $4.60^{\mathrm{ab}}$ \\
\hline VIII & $\begin{array}{l}\text { Synth. yellow } \\
\text { xantophylls, } 40 \mathrm{mg}\end{array}$ & 12.1 & $8.55^{\mathrm{abc}}$ & $29.4^{\mathrm{b}}$ & 32.4 & $2.24^{\mathrm{b}}$ & $7.34^{\mathrm{a}}$ & 0.737 & $3.85^{\mathrm{a}}$ \\
\hline EN & & 0.27 & 0.15 & 0.37 & 0.37 & 0.06 & 0.34 & 0.03 & 0.28 \\
\hline
\end{tabular}

a,b,c - means in columns with different letters differ significantly at $\mathrm{P} \leq 0.05$

Table 6. Selected groups of fatty acids ( $\%$ of fatty acids) and ratios in stored breast meat

\begin{tabular}{|c|c|c|c|c|c|c|c|c|c|}
\hline Group & $\begin{array}{c}\text { Supplement } \\
\cdot \mathrm{kg}^{-1}\end{array}$ & SFA & UFA & PUFA & $\begin{array}{c}\text { PUFA } \\
\text { n-6 }\end{array}$ & $\begin{array}{c}\text { PUFA } \\
\mathrm{n}-3\end{array}$ & $\begin{array}{c}\text { UFA/ } \\
\text { SFA } \\
\end{array}$ & $\begin{array}{c}\text { PUFA/ } \\
\text { SFA }\end{array}$ & $\begin{array}{c}n-6 / \\
n-3 \\
\end{array}$ \\
\hline I, control & - & 20.1 & 79.9 & 48.8 & 39.7 & $7.26^{\mathrm{ab}}$ & 4.00 & 2.45 & $5.59^{\mathrm{ab}}$ \\
\hline II & Vitamin E, $150 \mathrm{mg}$ & 21.4 & 78.6 & 51.3 & 40.7 & $8.83^{\mathrm{ab}}$ & 3.70 & 2.41 & $4.66^{\mathrm{ab}}$ \\
\hline III & $\begin{array}{l}\text { Coneflower extract, } \\
560 \mathrm{mg}\end{array}$ & 22.1 & 77.9 & 47.9 & 37.7 & $8.46^{\mathrm{ab}}$ & 3.56 & 2.20 & $4.49^{\mathrm{a}}$ \\
\hline IV & $\begin{array}{l}\text { Thyme extract, } \\
560 \mathrm{mg}\end{array}$ & 20.5 & 79.5 & 49.5 & 39.4 & $8.31^{\mathrm{ab}}$ & 3.92 & 2.44 & $4.96^{\mathrm{ab}}$ \\
\hline $\mathrm{V}$ & Sage extract, $560 \mathrm{mg}$ & 21.0 & 79.0 & 52.0 & 41.4 & $9.15^{\mathrm{b}}$ & 3.78 & 2.49 & $4.54^{\mathrm{a}}$ \\
\hline VI & $\begin{array}{l}\text { Marigold } \\
\quad \text { xantophylls, } 20 \mathrm{n}\end{array}$ & 21.1 & 78.9 & 49.9 & 39.3 & $8.73^{3 \mathrm{a}}$ & 3.77 & 2.38 & $4.64^{\mathrm{ab}}$ \\
\hline VII & $\begin{array}{l}\mathrm{BHT}+\mathrm{EQ}+\mathrm{BHA}, \\
48.6 \mathrm{mg}\end{array}$ & 22.5 & 77.5 & 49.1 & 40.5 & $7.18^{\mathrm{ab}}$ & 3.46 & 2.19 & $6.01^{\mathrm{b}}$ \\
\hline VIII & $\begin{array}{l}\text { Synth. yellow } \\
\text { xantophyll, } 40 \mathrm{mg}\end{array}$ & 21.1 & 78.9 & 48.3 & 39.8 & $6.83^{\mathrm{a}}$ & 3.75 & 2.30 & $5.93^{\mathrm{b}}$ \\
\hline SEM & & 0.27 & 0.48 & 0.43 & 0.35 & 0.25 & 0.06 & 0.05 & 0.17 \\
\hline
\end{tabular}

a, b - means in columns with different letters differ significantly at $\mathrm{P} \leq 0.05$ 
numerically lower level of PUFAn-3 was found in breast meat lipids from chickens fed the control diet and diet supplemented with synthetic xantophyll or synthetic antioxidants.

Supplementation of the basal diet with vitamin E, plant extracts, marigold xanthophylls or synthetic antioxidants had no positive effect on the TBA-RS value in stored meat, and addition of marigold xanthophylls even significantly increased TBA-RS content (Table 7). The content of vitamin $\mathrm{E}$ in breast meat of chickens fed diets enriched with $150 \mathrm{mg} \alpha$-tocopheryl acetate was nearly four times larger than in the control group (Table 7). Diet supplementation with

Table 7. TBA-RS ( $\mathrm{mg}$ of malonodialdehyde $\cdot \mathrm{kg}^{-1}$ ), vitamin E content $\left(\mathrm{mcg} \cdot \mathrm{g}^{-1}\right)$ and sensory properties of stored breasts (scored 2-5 points)

\begin{tabular}{|c|c|c|c|c|c|c|c|}
\hline Group & $\begin{array}{l}\text { Supplement, } \\
\cdot \mathrm{kg}^{-1}\end{array}$ & TBA-RS & $\begin{array}{l}\text { Vita- } \\
\text { min E }\end{array}$ & Flavour & Taste & $\begin{array}{l}\text { Tender- } \\
\text { ness }\end{array}$ & Juiciness \\
\hline I, control & 1 & $0.381^{\mathrm{a}}$ & $1.72^{\mathrm{a}}$ & $4.37^{\mathrm{b}}$ & $4.42^{\mathrm{bc}}$ & 4.47 & 4.42 \\
\hline II & Vitamin E, $150 \mathrm{mg}$ & $0.389^{\mathrm{a}}$ & $6.45^{\mathrm{b}}$ & $4.37^{\mathrm{b}}$ & $4.45^{\mathrm{bc}}$ & 4.53 & 4.42 \\
\hline III & $\begin{array}{l}\text { Coneflower extract, } \\
560 \mathrm{mg}\end{array}$ & $0.404^{\mathrm{a}}$ & $1.80^{\mathrm{a}}$ & $4.48^{\mathrm{b}}$ & $4.38^{\mathrm{bc}}$ & 4.65 & 4.57 \\
\hline IV & Thyme extract, $560 \mathrm{mg}$ & $0.392^{\mathrm{a}}$ & $1.89^{\mathrm{a}}$ & $4.45^{\mathrm{b}}$ & $4.52^{\mathrm{c}}$ & 4.56 & 4.62 \\
\hline V & Sage extract, $560 \mathrm{mg}$ & $0.455^{\mathrm{ab}}$ & $1.87^{\mathrm{a}}$ & $4.37^{\mathrm{b}}$ & $4.47^{\mathrm{bc}}$ & 4.46 & 4.43 \\
\hline VI & $\begin{array}{l}\text { Marigold xantophylls, } \\
20 \mathrm{mg}\end{array}$ & $0.520^{\mathrm{b}}$ & $2.02^{\mathrm{a}}$ & $4.29^{\mathrm{ab}}$ & $4.22^{\mathrm{ab}}$ & 4.34 & 4.34 \\
\hline VII & $\mathrm{BHT}+\mathrm{EQ}+\mathrm{BHA}, 48.6 \mathrm{mg}$ & $0.447^{\mathrm{ab}}$ & $1.76^{\mathrm{a}}$ & $4.24^{\mathrm{ab}}$ & $4.25^{\mathrm{abc}}$ & 4.39 & 4.39 \\
\hline VIII & $\begin{array}{l}\text { Synth. yellow } \\
\text { xantophylls, } 40 \mathrm{mg}\end{array}$ & $0.461^{\mathrm{ab}}$ & $1.84^{\mathrm{a}}$ & $4.06^{\mathrm{a}}$ & $4.00^{\mathrm{a}}$ & 4.31 & 4.23 \\
\hline SEM & & 0.01 & 0.25 & 0.03 & 0.03 & 0.04 & 0.04 \\
\hline
\end{tabular}

a,b,c - means in columns with different letters differ significantly at $\mathrm{P} \leq 0.05$

synthetic xantophyll negatively influenced $(\mathrm{P}<0.05)$ the smell and taste of boiled breast meat (Table 7). Nevertheless, in all groups, stored breast meat was found to be suitable for consumption.

\section{DISCUSSION}

The results of the present study indicate that dietary supplementation with natural plant extracts chosen for their antioxidative properties or with synthetic antioxidants or pigments did not affect the performance of broiler chickens fed a balanced maize-soyabean diet. However, some authors have found improved performance when active plant substances were added as a substitute for antibiotic growth promotors in chickens (Horton et al., 1991, Jamroz et al., 2003).

The lipids of the basal diet containing $4 \%$ rape seed oil and $1 \%$ of fish fat, were relatively rich in oleic acid, linoleic acid, linolenic acid, EPA and DHA. This diet ensured a satisfactory level of PUFA in breast meat lipids of control chickens. Some 
of the investigated additives affected the fatty acid profile of stored breast meat lipids. Supplementation of the diet with sage extract increased the levels of stearic acid, arachidonic acid, DHA and PUFA n-3 and decreased the level of monounsaturated oleic acid and polyunsaturated $\alpha$-linolenic acid in comparison with the control group and chickens fed synthetic xantophyll. The PUFA n-6/n-3 ratio was also lowered as a result of adding sage. These results may suggest an effect of sage extract on fat metabolism. The effect of plant extracts on fatty acid profiles was reported in fattening pigs (Hanczakowska and Świątkiewicz, 2006; Szewczyk et al., 2006). A reduction of monounsaturated fatty acids and increase of PUFA in muscle fat of pigs fed nettle extract was confirmed by a decrease of cholesterol and triacylglicerol concentrations in blood serum (Szewczyk et al., 2006).

Synthetic xantophyll or mix of synthetic antioxidants (BHT+EQ+BHA) had no effect on the fatty acid profile of fat in stored breast meat. In the case of BHA similar results were reported in muscle of pigs (Hanczakowska and Świątkiewicz, 2006).

Natural plant extracts with antioxidative proprieties or synthetic antioxidants or pigments added to the diet had no positive effect on TBA-RS values of stored breast meat compared with the control diet. In case of marigold xantophylls added to the diet, the effect in stored meat was even negative. Woodall et al. (1996) stated that dietary $\beta$-carotene and zeaxanthin supplementation of chicken diets significantly reduced in vitro susceptibility of liver to oxidation (TBA-RS) and nonsignificantly in breast muscle homogenates. Canthaxantin did not protect tissues against oxidation, whereas supplementation with $\alpha$-tocopherol $\left(100 \mathrm{mg} \cdot \mathrm{kg}^{-1}\right)$ had a significant antioxidative effect in muscle.

Dietary supplementation with $500 \mathrm{mg} \cdot \mathrm{kg}^{-1}$ rosemary or sage extract decreased the TBA-RS content in broiler breast meat stored for 4 months or cooked (LopezBote et al., 1998). The antioxidant activities of sage extracts were higher than those of oregano (Pizzale et al., 2002). In poultry, improved abdominal fat oxidative stability was observed as a result of supplementing BHT and ethoxyquin to diets (Bartov and Bornstein, 1981).

A relatively low TBA-RS content in stored breast meat was found in chickens fed a control diet that contained in $1 \mathrm{~kg} 15.9 \mathrm{mg}$ of $\alpha$-tocopherol originated from natural feed components. Similar TBA-RS values were found in meat when the diet contained $160.7 \mathrm{mg} \alpha$-tocopherol, e.g., supplemented with $150 \mathrm{mg} \alpha$-tocopheryl acetate. Both levels of vitamin $\mathrm{E}$ in the diet correspond to 1.7 and $6.4 \mathrm{mcg}^{-1} \mathrm{~g}^{-1} \alpha$-tocopherol in stored breast meat. The results of the present study suggest that the natural vitamin E content in the rape seed oil diet ensured as good anti-oxidative protection of meat as a four-fold higher vitamin $\mathrm{E}$ level. However, in our earlier experiment (Koreleski and Świątkiewicz, 2006) addition 150 or $300 \mathrm{mg} \cdot \mathrm{kg}^{-1} \alpha$-tocopheryl acetate to a diet containing $8.1 \mathrm{mg} \cdot \mathrm{kg}^{-1}$ of natural $\alpha$-tocopherol, lowered the TBA-RS value in stored breast meat. A lower TBA-RS content was also noted in refrigerated turkey breast meat supplemented with $180 \mathrm{mg} \alpha$-tocopheryl acetate (Sheldon et al., 1997). 
Stored breast meat was found to be suitable for consumption, but the effect of additives on the taste and smell of meat was not the same. Dietary synthetic xantophyll negatively influenced sensory indices in boiled meat, but the worse taste and smell were not of the rancid type. Plant extracts of coneflower, thyme and sage in the diet did not affect the flavour or taste of stored boiled meat as compared with the control diet or the diet supplemented with $\alpha$-tocopheryl acetate. These results are in agreement with data reported by Gardzielewska et al. (2003), who found no effect in broilers of herbal supplements (coneflower, garlic or ginger) on the sensory properties of boiled breast meat after 4 months of frozen storage.

\section{CONCLUSIONS}

Sage extract added to the diet can beneficially affect the fatty acid profile of stored breast meat lipids in chickens. Under the conditions of meat storage in this experiment, the natural vitamin E content in the rape seed oil-containing diet provided equivalent anti-oxidative protection of meat as the diet supplemented with $150 \mathrm{mg} \alpha$-tocopheryl acetate.

\section{ACKNOWLEDGEMENTS}

The supply of vitamin-mineral premix and vitamin E as gift from BASF Premixes, LTD. Kutno (Poland) is gratefully acknowledged.

\section{REFERENCES}

Abd El-Alim S.S.L., Lugasi A., Hovari J., Dworschak E., 1999. Culinary herbs inhibit lipid oxidation in raw and cooked minced meat patties during storage. J. Sci. Food Agr. 79, 277-285

AOAC, 1990. Association of Official Analytical Chemists, Official Methods of Analysis. 15 Edition. Arlington, VA

Bandonien D., Venskutonis P.R., Gruzdiene D., Murkovic M., 2002. Antioxidative activity of sage (Salvia officinalis L.), savory (Satureja hortensis L.) and borage (Borago officinalis L.) extracts in rapeseed oil. Eur. J. Lipid Sci. Technol. 104, 286-292

Bartov I., Bornstein S., 1981. Stability of abdominal fat and meat of broilers: Combined effect of dietary vitamin E and synthetic antioxidants. Poultry Sci. 60, 1840-1845

Dapkevicius A., Venskutonis R., Van Beek T., Linssen J.P.H., 1998. Antioxidant activity of extracts obtained by different isolation procedures from some aromatic herbs grown in Lithuania. J. Sci. Food Agr. 77, 140-146

European Table of Energy Values for Poultry Feedstuffs, 1989. WPSA, Wageningen (The Netherlands)

Folch J., Lees M., Stanley G.H.S., 1957. A simple method for the isolation and purification of total lipids from animal tissues. J. Biol.Chem. 2226, 497-509 
Fuhrman B., Rosenblat M., Hayek T., Coleman R., Aviram M., 2000. Ginger extract consumption reduces plasma cholesterol, inhibits LDL oxidation and attenuates development of atherosclerosis in atherosclerotic, apolipoprotein E-deficient mice. J. Nutr. 130, 1124-1131

Galobart J., Barroeta A.C., Baucells M.D., Codony R., Ternes W., 2001. Effect of dietary supplementation with rosemary extract and $\alpha$-tocopheryl acetate on lipid oxidation in eggs enriched with $\omega 3$-fatty acids. Poultry Sci. 80, 460-467

Gardzielewska J., Pudyszak K., Majewska T., Jakubowska M., Pomianowski J., 2003. Effect of plant-supplemented feeding on fresh and frozen storage quality of broiler chicken meat. Electron. J. Polish Agr. Univ., Ser. Anim. Husb. 6, 2, http://www.ejpau.media.pl

Giannenas I.A., Florou-Paneri P., Botsoglou N.A., Christaki E., Spais A.B., 2005. Effect of supplementing feed with oregano and/or $\alpha$-tocopheryl acetate on growth of broiler chickens and oxidative stability of meat. J. Anim. Feed Sci. 14, 521-535

Halvorsen B.L., Holte K., Myhrstad M.C.W., Barikmo I., Hvattum E., Remberg S.F., Wold A.B.,Haffner K., Baugerod H., Andersen L.F., Moskaug O., Jacobs D.R., Blomhoff R., 2002. A systematic screening of total antioxidants in dietary plants. J. Nutr. 132, 461-471

Hanczakowska E., Świątkiewicz M., 2006. The effect of lemon balm (Melissa officinalis L.) or hop (Humulus upulus L.) extracts on pig meat quality. Anim. Sci. 1, Suppl., 168-169 (Abstr.)

Horton G.M.J., Fennell M.J., Prasad B.M., 1991. Effect of dietary garlic (Alium sativum) on performance, carcass composition and blood chemistry changes in broiler chickens. Can. J. Anim. Sci. 71, 939-942

Jamroz D., Orda J., Kamel C., Wiliczkiewicz A., Wertelecki T., Skorupińska J., 2003. The influence of phytogenic extract on performance, nutrients digestibility, carcass characteristic and gut microbial status in broiler chickens. J. Anim. Feed Sci. 12, 583-596

Jeremiah L.E., 1980. Effect of frozen storage and protective wrap upon the cooking losses, palatability, and rancidity of fresh and cured pork cuts. J. Food Sci. 45, 187-187

Koreleski J., Świątkiewicz S., 2006. The influence of dietary fish oil and vitamin E on fatty acid profile and oxidative stability of frozen stored chicken breast meat. J. Anim. Feed Sci. 15, 631-640

López-Bote C.J., Gray J.L.,Gomaa E.E., Flegal C.J., 1998. Effect of dietary administration of oil extracts from rosemary and sage on lipid oxidation in broiler meat. Brit. Poultry Sci. 39, 235-240

Manz U.Y., Philipp K., 1981. A method for the routine determination of tocopherols in animal feed and human foodstuffs with the aid of high performance liquid chromatography. Int. J. Vitamin. Nutr. Res. 51, 342-348

Morrison W.R., Smith L.A., 1964. Preparation of fatty acid esters and dimethylacetals from lipids with boron fluoride-methanol. J. Lipid Res. 5, 600-608

Pikul J., Leszczyński A., Kummerow F.A., 1989. Evaluation of three modified TBA methods for measuring lipid oxidation in chicken meat. J. Agr. Food Chem. 37, 1309-1317

Pizzale L., Bortolomeazzi R., Vichi S., Uberegger E., Conte L.S., 2002. Antioxidant activity of sage (Salvia officinalis and S. fruticosa) and oregano (Origanum onites and O. indercendens) extracts related to their phenolic compound content. J. Sci. Food Agr. 82, 1645-1651

Salih A.M., Smith D.M., Dawson L.E., 1987. Modified extraction 2-thiobarbituric acid method for measuring lipid oxidation in poultry. Poultry Sci. 66, 1483-1488

Sheldon B.W., Curtis P.A., Dawson P.I., Ferket P.R., 1997. Effect of dietary vitamin E on the oxidative stability, flavour, coluor and volatile profiles of refrigerated and frozen turkey breast meat. Poultry Sci. 76, 634-641

Szewczyk A., Hanczakowska E., Świątkiewicz M., 2006. The effect of nettle (Urtica dioica) extract on fattening performance and fatty acid profile in the meat and serum lipids of pigs. J. Anim. Feed Sci. 15, Suppl. 1, 81-84

Woodall A., Britton G., Jackson M.J., 1996. Dietary supplementation with carotenoids: effect on $\alpha$-tocopherol levels and susceptibility of tissues to oxidative stress. Brit. J. Nutr. 76, 307-317 